骨 盤 肉腫の 2 例

$\begin{array}{lllll}\text { 国立大村病院整形外科 } & \text { 清 } & \text { 水 } & \text { 通 } & \text { 生 } \\ & \text { 牟 } & \text { 田 } & \text { 義 } & \text { 人 } \\ \text { 長崎労災病院整形外科 } & \text { 大 } & \text { 島 } & \text { 和 } & \text { 二 }\end{array}$

\title{
Two Cases of Pelvic Sarkoma
}

By

M. Shimizu, Y. Muta

(Orthopedic Clinic, Ōmura National Hospital)

and K. Ōshima

(Orthopedic Clinic, Nagasaki Labour Accident Hospital)

骨肉腫は骨腫㑥中非常にしばしば見られるるのであ り，その予後の不良なる事と，好んで若年者を犯す事 に於て愿にも勝る悪性腫韵と考えられる．かくの如き 肉腫子その発生部位が四肢の比較的末梢部にあり，か つ早期発見が行わ得るならば切断術によつてその治 瘾率を増加せしめ得るであろらが, 骨盤等に発生した るのは抗随海剂の投与, 上線治療に上る以外に方法は ない，最近吾々は骨盤肉畽の 2 例を経験したので報告 します。

症例 I. 51 才男子工員.

生来著患を知らず，約 2 ケ月前歩行中に転倒し，鉄 材にて右腸骨部を強打し，同部に疼痛強く，レ線像に 異常なしとの事で吪法, 注射等の治療を受け, 約 1 ケ 月で疼痛は軽くなつたが最近再び同部に疼痛增強し睡

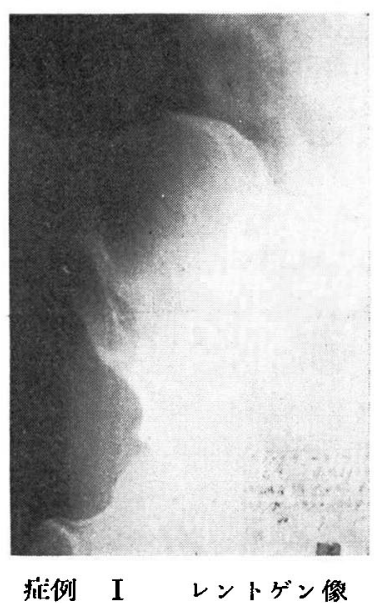

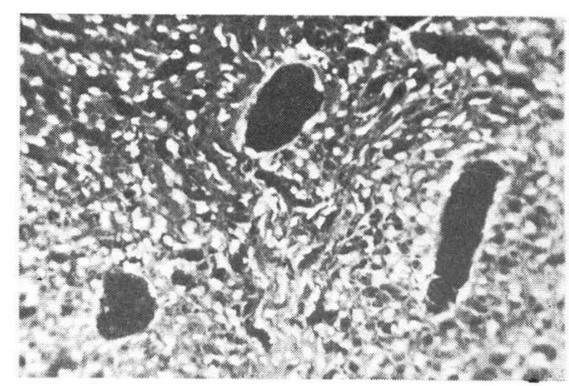

瘤例 I 狱理組 織

脹が現れた. 特に運秒痛強く, 歩行不能である. 家族 歷に異常はない。

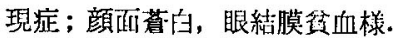

局所々見；右股関䬣柽度内転屈曲位，右大腿上部上 り腸骨部にかけ烥脹. 弹性硬, 局所熱感出り, 発赤, 静脉怒張な乙. 圧痛は腫脹部全体にあるが特に右上前

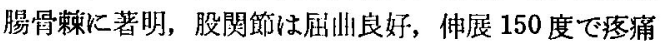
著明, 内外転はやや制限さる。

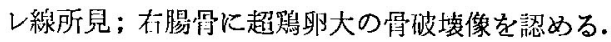
肺その他の骨に異常は梽めない。

臨休検查所胃; 表 1 .

患老は骨髄炎の疑いで入院せしめ抗生物質の投与を 行つたが変化なき為腫湯を疑い試験切除を行つた。

病理組織所見：一層の内皮細胞で扣扮われた多数の

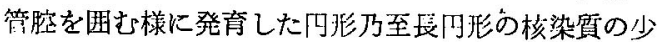
い細胞が卞体をなし，管腔に赤响球を谷れたすのもあ

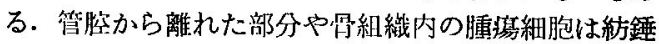

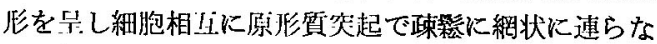
つた部もむる.これらの像は渐進的移行を示す。 


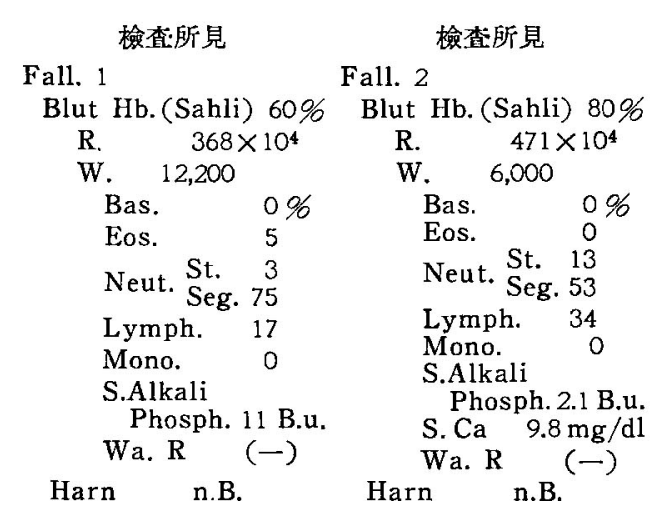

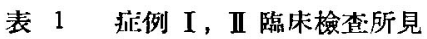

診断; Haemoangiopericytoma.

試験切除後レ線照射 3 回行つたが, 患者の希望で退 院し約 2 ケ月後に死亡した。

症例 II. 35 才男子 会社員.

昭和 32 年 1 月諉因なく左坆部に軽度の疼痛があり， 放置していた３月自転車にて転倒し石で左腸骨部を 強打した. 以後疼痛の為寝返りる不能となつた. 某医 にイルガピリンの注射を数回受けたが無效で放置して 軽快した. 33 年 1 月左晹骨部の腫脹, 左大敘伸側の シビレ感起り，疼痛も再発した。特に夜間に著明であ つた. 3 月末骨䯣炎の診断にて抗生物質を投与したが 無効の為腆演を疑い入院せしぬた。

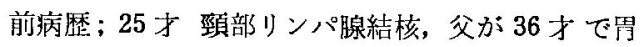
癌の為死亡している。

現症；顔面荅白，その他に著变はない。

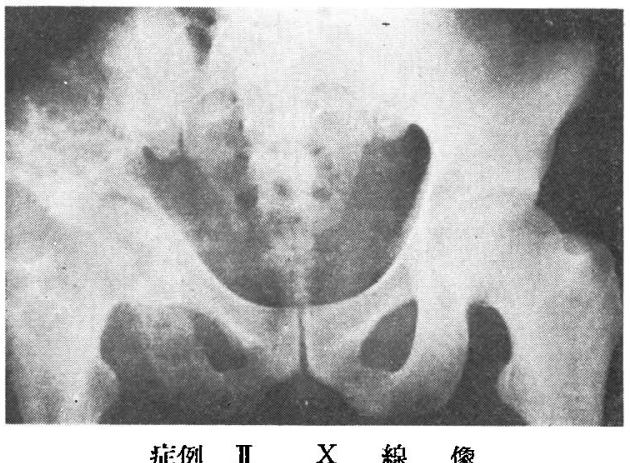

局所々見; 左鼠径部, 大転子部, 䠌部に腫脹著明, 圧痛あり，局所熱感なし．左下肢に筋萎縮あり，股関 節屆曲 45 度 をで, 伸展良好, 内外施障碍, 内外転軽 度障碍さる。

レ線所見；左腸骨，坐骨に雲䋈状の骨破罗像あり， 後には大眼骨にる及んだ.肺には変化はない。 臨床検查所見；表 I

患者は試験切除後カルチノフィリン 2,000 単位を 2 日，5,000 単位を 7 日間連続投与を行つたが全身倦㤐， 悪心，嘔姓の為に中止した。入院 2 ケ月後急に下腹痛 を訴光，尿閉を来し，泌尿器科にて膀胱出血の診断て Blasenfistel の手術を受けた. 膀脱出血治療後 Kastration を行い, 同時にテスパミンを $0.5 \mathrm{cc} 6$ 日間筋 注したが再び副作用の為中止した１0月 患者の希望 で退院し, 11 月に死亡した。

病理組織所見：骨組轼；骨梁は萎縮性で骨髄組織は 全くなく絬合織増殖し，一部に Fibrom 一部に肉芽組 織，又一部に Fibrosarkom の如き構造を有する. 軟 部組織は Folymorphzelliges Sarkom の状態で所々 に Fibrom, Fibrosarkom の像を呈する.

診断; Fibrosarkom.

\section{考察;}

第 1 例は腫湟の 発生と外傷との 関係が考えられる が, Thiem の四原則より見れば 1) 外賃が相当の強 さを有する事，2）外賃に上る傷害部位と肉腫発生部 位とが一致する事，3）受傷より肉腫発生までの間, 他覚的或は自覚的に症状が継続している事，4）受倁 後肉腫発生までの期間が 3 週乃至 2 年なる事, の各条 件の内 1）2）3）の各項には本例は一応適合している と思われるが，4）の条件に於ては種々なる意見があ り, 最短 3 ケ月, 平均 10 ケ月としている人るむる. 本例では約 2 ケで，その期間がやや短い様に思われ る. 従つて発生原因として外傷と断定する事は出来な いが，何等かの発育促進因子として作用していると考 えられないであろうか. 又病理組織では血管周皮細胞

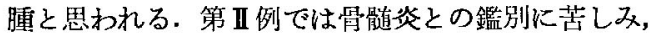
病理所見子複雑で結合織の增殖 Fibrom 様の変化, Fibrosarkom の像等から，その発生の様相を現して いるものと考えられる. 治療ではカルチ.ノフィリン， テスパミンを使用したが短期投与の為か，特に热むべ き効果は無かつた.

\section{兵 問}

九大天児民和

鳥取大学桑原教授は骨船切除の多くの経験を有して 居られるので, 只今の報告例には其適応はむるかどう か御考えを教えて頂きたい。 
追 加

$$
\text { 鳥取大学 桑原 }
$$

覀性 腫昜に 骨盤切除を 最適当と思うほどでなかつ た.ただその際, 主静脉を含めて諸静脉を先ず結禁し， 後動脉結紮を行うことを自ら注意した。
追 加

神戸医大整形 柏木大治

大眼骨上端から発生した肉腫に対して hind-quarter-amputation をなした。

術後 2 年後に肉腫は局所に再発 Anurie となつて死

亡した症例の経験を追加する.

\title{
広沉なる転移を起こした骨細網肉腫と思われる一例
}

\author{
長崎大学医学部整形外科（主任: 永井三郎教授） \\ 朝 長一 一 原和夫 \\ 村田敬 典 岡本 雄 三
}

\section{A Case of Primary Reticulum Cell Sarcom of Bone with Wide Spread Involvement in Skeletal System.}

By

\author{
H. Tomonaga, K. Mihara, Y. Murata \\ and Y. Okamoto \\ Department of Orthopedic Surgery, School of Medicine, \\ Nagasaki University (Director: Prof. S. Nagai)
}

Oberlingは骨の Reticuloendothelial より原発する 畽瘍に対して骨原発性細網肉腫と名ずけ Parker and Jackson が臨床的及び組織学的見地からこの細網肉腫 の本態について論じ, Edwards, Sherman and Snyder はこの畽昜のレ線所見からこれら 細網肉腫を考察し た. その後 Coley, Mc. Comack, Ivins and Dahlin, Hausberg and Kenin, Schobinger 等がこの細網肉 腫の臨床的, レ線的, 組織学的な所見から診断を下し た多数の症例, 報告がある. 最近吾々も骨の細網肉腫 と思える 1 例を経験し， しかも殆んどの全身骨に転位 を起こしたもので他の骨腫瘍と鑑別上非常に困難であ つたが，臨床的経過，レ線所見及び組織学的検索の結 果一応細網肉腫と断定さるべきものであると考えられ るので報告する次第である.

\section{症例： 合 27 才商業.}

既往歴, 家族歴：に特記すべきものはない.

現病歴：昭和 33 年 8 月 10 日頃から何等誘因と思 えるものなく背部痛を訴えるようになり，某医に受診 肋間神経痛と診断され対症療法を受けていたが疼痛は 消退することなく次第に増加したため 10 月に入つて 他の医師に医療を乞い胸部レ線撮影を受け肋骨カリエ
スと診断され入院の上，P.A.S. 及び S.M. の使用を受 けた。

1 ケ月後やや症状は軽快したので退院し，その後自 宅で様子をみるよう指示され休養をとつていたが，軽 度の疼痛を背部から腰部にかけて感じていたと云う。 34 年 1 月 10 日階段よりころげ落ちて腰部を強打し, その後より強烈な腰痛を招来し, 坐位, 立位, 歩行に 際しても又仰臥位に対しても痛みを感じ，側卧位で安 静を保つていたと云5．2月 10 日頃から咳嗽，喀痰 が出るようになり，咳嗽に際して腰部から左脚に放散 する痛みを感じるようになつた。2月 25 日頃から熱 発し, 腰痛も増強せる為 2 月 28 日吾々の外来を訪門 した. 初診時一般状態悪く起立, 坐居不能で, 右側臥 位をとり両下肢は屈曲位でやや拘縮をきたし，背部， 腰部に圧痛があり，左膝関節にも疼痛を訴えた。しか し局所に熱感も腫脹も触知しなかつた. 直ちに入院し 胸部, 腰部, 左膝関節のレ線撮影を行つたところ右第 6 胁骨, 左第 8 助骨に溯漫性に腫脹せる骨硬化像を認 め, 左鎤骨に円形の透明肩，又第 III腰椎に著明な骨破 壊像, 左大眼骨, 脛骨, 腓骨の Metaphyse から Diaphyseにかけて打抜き様の透明巣を認めた。しかし胸 